\title{
'Soldiers of God or Allah': Religious Politicization and the Boko Haram Crisis in Nigeria
}

\section{by Benjamin Maiangwa}

\section{(cc) BY}

This work is licensed under a Creative Commons Attribution 3.0 License.

\begin{abstract}
Several works on Boko Haram have underscored the issues of state weakness and bad governance in Nigeria as the major problematic fuelling the group's violent activities. While the state fragility argument is indispensable, this paper argues that the religious dimension is also critical to any attempt to understand the Boko Haram crisis. To this end, the paper will examine how the historical and contemporary processes of religious politicization in Nigeria have contributed to the rise and radicalization of Boko Haram.
\end{abstract}

Keywords: religious politicization, state weakness, bad governance, Boko Haram, terrorism, northern Nigeria,

\section{Introduction}

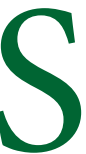
ince its radical uprising in July 2009, Jama'atu Ahlis Sunna Lidda'awati Wal-Jihad (Association for propagating the Prophet's Teachings and Jihad), commonly called Boko Haram (Western education/ civilization is profane) has become an embodiment of insecurity, fear, and suicide bombings in Nigeria. The group has emerged as the most violent of the religious sects bent at imposing Sharia law in Nigeria (Salifu, 2012). Together with alleged killings by the Nigerian security forces, Boko Haram's attacks have left more than 4, 000 people dead with attendant consequences on the economy and political stability of Nigeria (Aljazeera 13 August, 2013).

Several theories have been put forward to explain the rise and radicalization of Boko Haram. The Economist Magazine (cited in Mustapha, 2012) reports that Boko Haram represents the attempt by disenfranchised youths in northern Nigeria to demand for similar kind of amnesty fund and opportunities given to the Niger-Delta militants by the late President Yar'adua Administration. The prevailing view in southern Nigeria is that Boko Haram is the proxy of northern politicians who are geared towards discrediting the government of a southern-Christian President (Mustapha, 2012). On his part, Onuoha (2010: 65) notes that the Boko Haram terrorism is simply a symptom of the failings of the Nigerian state. Admittedly, the experience of most Nigerians has not led to a deep level of trust between the government and the governed. This, in turn, has contributed to an environment in which Islamist militant ideologies resonate. And then there is the issue of poverty and unemployment, both widespread in Nigeria, but pervasive in the northern region and particularly in the north-east state of Borno - Boko Haram's geographic centre of gravity, where social welfare indicators on health, employment, and education are generally weak. Within such an impoverished environment, Castells (2004) observes that the appeal of religious fundamentalism could easily come together with social and economic reform.

Whilst the dismal socio-economic conditions in some parts of northern Nigeria do not fully account for the rise and radicalization of Boko Haram, such conditions, nevertheless, provided the group's initial leader - late 
Mohammed Yusuf - with the favourable atmosphere to establish the Boko Haram movement. Yet, one of the noticeable characteristics of the Boko Haram phenomenon is its religiosity, which has largely been woven into its fabric by political processes in Nigeria. In this sense, it is important to elaborate on and understand the processes of religious politicization in Nigeria as they relate to the rise of Boko Haram. To this end, part one of the paper offers some theoretical insights on religious politicization. Part two explains how religion has become an integral part of political fields of contestation in Nigeria. Here also, the rise of Boko Haram and other forms of religious extremism in Nigeria is contextualized within the processes of religious politicization. Part three reflects on some possible recommendations that could help to manage the Boko Haram crisis and other related issues in Nigeria.

\section{Religious Politicisation}

All religions reek with the blood of human carnage, not because God is blood thirsty but because in the primordial irony, man [sic] created a god limited by man's own weaknesses; lust for a political power base, and economic dominance (Ibrahim, 1991: 129-30).

Historically, religion has been used as an instrument of social cohesion in many societies. At the same time, however, religion has also been adroitly contrived into an instrument of violence, "hence its indication in some literature as a double-edged sword" (Sampson, 2012: 104). At the turn of the twentieth century, Karl Marx and Max Weber predicted the demise of religion and the imminence of secularism. But events in the 21st century, especially the spates of religious violence in many societies around the world, suggest the continued pre-eminence, perpetuity and persistence of religion (Jefferis, 2010: 1). This is further demonstrated in such religious-based wars as the 1979 Islamic revolution in Iran, the altercations between the Muslims and the Buddhists in Sri Lanka, the festering war in Sudan, the longstanding Israeli-Palestinian conflict, the Sunni-Shi'a war in Iraq, the September 11 terrorist attacks and the Arab Spring (Agbiboa, 2012: 207). Additionally, Hoffman (1998: 89) argues that the ethos of self-sacrifice and suicidal martyrdom carried out in the name of God can be seen in many religious terrorist organizations, and have grown exponentially in recent times with considerably higher levels of casualties. For instance, Hoffman (1999: 17) observes that groups motivated in part or in whole by religious ideology committed some of the high-profile terrorist attacks that were documented in 1996. These include:

The Palestinian Islamic Resistance Movement, Hamas, responsible for three incidents (which killed 56 persons); the Jammu and Kashmir Liberation Front for two (killing 37); a shadowy Saudi Arabian dissident group for two (causing 30 fatalities); the Egyptian al-Gama'a al-Islamiya for one (18 persons died); unspecified Kashmiri rebels for another incident (where eight persons died); and the Turkish Islamic Jihad for the remaining one (in which 17 persons perished) (Hoffman, 1999: 17).

The foregoing events demonstrate that while it is instrumental for communal harmony, religion could also be utilized in the achievement of certain political and other established needs and interests (Sampson, 2012: 104). As Baylis and Smith (2001: 495) argue, religion could be turned into a doctrine of action and hatred, where spiritual achievement occurs through destruction rather than personal enlightenment.

In a study undertaken in Spain, it is reported that societies divided along religious lines are more susceptible to intense conflicts than those divided by political, territorial and ethnic differentiations (Sampson, 2012: 104). In Nigeria, the political, territorial, and ethnic differences are all important sources of conflicts. But, perhaps, the religious factor has predominated and as such, explains the prolonged nature and dimension that religious violence had assumed in the country. The rest of the paper will show that while other conflict 


\section{Journal of Terrorism Research}

multipliers in Nigeria such as ethnicity and the prevailing socio-political, economic, and cultural issues, are important in understanding violent conflicts in the country, the religious dimension, especially its politicization, is worth looking into when trying to provide a nuanced understanding of the Boko Haram phenomenon.

\section{Religious Politicization and the Emergence of Violent Extremist Groups in Nigeria}

Since the time of Usman Dan Fodio's Jihad in the 19th century, differences in religious belief in Nigeria have been sighted as categories of exclusion and violent conflicts. In 1802, Usman Dan Fodio (1754-1817), a religious and political leader of Fulani descent, launched a jihad in order to reform what he regarded as ungodly practices of the Hausa rulers and aristocrats whom he considered as anti-Islamic (Maier, 2000: 150). He criticised them for what he perceived as their unjust rule, which included manslaughter, violating their honour, and devouring their wealth; and enforced upon them the Sharia law as the basis for ethical and principled leadership (Levitzon, 2000: 85). At their refusal, he overthrew them and established the Sokoto Caliphate - a federation of emirates comprising the states of Sokoto, Kano, Kaduna, Bauchi, Adamawa, Niger, Kwara, and some parts of Plateau (Paden, 1981: 24; Kenny, 1996: 339). By establishing the Caliphate system, Dan Fodio's jihad laid the foundation for the dominance and politicization of Islam in northern Nigeria. Although the Sokoto Caliphate eventually lost its legitimacy during the colonial occupation of Nigeria, the British colonialists, somehow, still maintained a mutually beneficial relationship with the local Muslim rulers by establishing an Anglo-Hausa/Fulani hegemony in what is regarded as the Indirect Rule system (Mu'azzam and Ibrahim, 2000: 79).

The Indirect Rule system, which was basically a system of colonial administration in Northern Nigeria that administered governance through the use of the region's traditional chiefs, vested the Muslim aristocrats with the political authority, which privileged them over non-Muslims living in the region (Haynes, 1996: 38). The British also integrated the pre-colonial Sharia Courts into the new colonial state. With such a religiouslyladened legal system, it was impossible to resolve conflicts or adjudicate on criminal offences without observing some of the tenets of the Sharia law. Christian religious personnel may have been unhappy with this arrangement, but generally lacked the political clout to attempt any changes to the system. In fact, in some occasions, Haynes (1996: 38) argues that Christian proselytizing was barred in Northern Nigeria at the behest of Muslim traditional chiefs. It was little wonder that at the end of colonialism, many Muslim elites found themselves in positions of political and religious influence to the chagrin of the Christians. According to Ibrahim (1991: 116), this led to the evolution of political strains and conflicts between the proponents of the two rival universal religions that the Middle East has bequeathed to Nigeria and the world over.

Following the attainment of political independence on 1 October 1960, many of the country's divisive and distorted colonial structures remained intact: "No consensual normative code governed expectations and behaviours in Nigerian post-independence politics, and even electoral victories were only expected to confirm the North's 'predetermined' right to rule; when they did not, they were rejected and subjected to reversal" (Gboyega, 1997: 150). This reality, coupled with the corruption and mismanagement of resources by the political elites, set the scene for the staging of bloody military coups in Nigeria. When the military first staged a coup on 15 January 1966 to 'intervene' in the political crisis of the time, their targets were the political class, particularly the dominant northern political elites like the Prime Minister (Sir Abubakar Tafawa Balewa), and the premiers of the Northern (Sir Ahmadu Bello) and Western (Samuel Akintola) regions. Since most of the coup plotters were of Igbo extraction, and the victims were all - except for Akintola - Muslim northerners, the inference drawn by many northerners was that the coup was a deliberate 


\section{Journal of Terrorism Research}

attempt by the southerners to obliterate northern politicians from the public space. This suspicion was heightened by the fact that the then commanding officer of the Nigerian Army, Major General Aguiyi Ironsi (himself an Igbo) did nothing to assuage the grief of the northerners. Worst still, Ironsi's decree introducing a unitary system of government in Nigeria left many northerners, especially the army chiefs, seething with anger (Gboyega, 1997: 165). At this stage, the signals for another coup, and possibly a war, were clear. Unsurprisingly, on 29 July 1966, Ironsi was toppled and killed, alongside his subordinates and many Igbo traders living in the north. This incident ignited the move for secession by the Igbos - the Biafran secession which metastasized into the Nigerian civil war (1967-70) (Ikelegbe, 2005: 77).

With the war over in 1970, the Yakubu Gowon Administration instituted many programs geared at promoting national unity and reconciliation. Poignantly, these curative programmes were impeded by the problem of absorbing the former supporters of State secession into the wider Nigerian society - since the stereotypes, resentments, and prejudices that had developed prior to and during the war period were still rife among the different ethnic and religious groups in the country (Falola \& Njoku, 2010: 333). The mismanagement of the reconciliation process led to a phase of identity-based clashes as aggrieved groups, parties, and individuals sought the restructuring of the country along religious and ethnic lines. Nowhere was this more obtrusive than at the constitutional conference (1977-78), where the issue of the Sharia law was heatedly debated (Gboyega, 1997: 156). According to Mu'azzam and Ibrahim (2000: 64), it was this heated Sharia debate that dragged the issue of politics and religion to the centre stage in Nigeria.

During the course of the Sharia debate, northern Muslims raised the issue of elevating the status of Sharia courts from the state level in the northern region to federal courts across the country. Liman (1977: 16 cited in Mu'azzam and Ibrahim, 2000: 64) was even more emphatic in recommending that "a Muslim vigilante group should be formed at the national level to alert the nation whenever they feel that Islamic interest in any place and at any level is being violated or sacrificed". The issue of establishing a federal court of appeal for Sharia cases was eventually dismissed and instead, a constitutional assembly reached a consensus - although frowned upon by the northern delegates - under which three Islamic law judges, while still being part of the Federal Court of Appeal, but not independent from it, could hear cases referred from the Sharia courts (Cook, 2011: 5). While the issue was being negotiated, the leaders of the Christian community in Nigeria also embarked on a campaign for the recognition of the Canon Law in the Nigerian constitution (Ibrahim, 1989: 77). Such debates and agitations, from both sides, constituted a major threat to the tenuous unity of the Nigerian state and also contributed to the rise and proliferation of "new forms of consciousness and militancy structured along religious lines" (Hunwick 1992: 149).

The religious movements that emerged during this period sought the reform and purification of the Nigerian society, "especially in the context of the class polarization in Nigeria during the oil-boom years of the 1970s and early 1980s" (Haynes, 1996: 218). This phase, which gained impetus with the Iranian revolution in the late 1970s, saw the rise of extreme religious groups like the Yan Izala, the Muslim Brotherhood, the Muslim Student Society (MSS), the Islamic Movement of Nigeria (IMN), the Dawa group, and several other Islamic splinter groups (Adesoji, 2010: 4). The Iranian revolution gave radical Muslims in Nigeria two significant examples; on the one hand, it gave them an immediately recognizable radical program for their own societies, and on the other hand, it offered them a political platform from which to launch attacks on incumbent Muslim elites, associated with some form of corruption or economic mismanagement (Haynes, 1996: 239). This kind of globalized religious solidarity reiterates the view in the field of political Islam, that militancy in the Muslim world is primarily a response to the desire to establish a global Islamic order as a religious duty, which is also driven by the belief in the notion that the West is at war with Islam (Neuman, 2013: 882). Other 


\section{Journal of Terrorism Research}

key international developments that evoked radical Islamic reactions in Nigeria during this period are the developments in the Middle East where views often expressed are in support of the Palestinians in what is seen as their struggle against Israel. In recent times, it is the United States' war against terrorism in Iraq and Afghanistan that have added to the creation of anti-Western animosity on the one hand, and the violent radicalization of certain Muslim groups in Nigeria on the other (Alao, 2009: 39).

Furthermore, the appeal of Islamic hegemony contributed to the manifestations of religious militancy among some groups that appear throughout the late 1970s in Nigeria, whose members remained committed to Islamic religious purity and anti-democratic/capitalist/Westernized objectives (Forest, 2012: 76). One example of these movements is the Maitatsine (the one who curses). According to Adesoji (2010: 1), the Maitatsine uprisings of 1980 in Kano, 1982 in Kaduna and Bulumkutu, 1984 in Yola and 1985 in Bauchi, represent the first violent attempts at imposing a strict version of religious ideology on a pluralistic, independent Nigeria by extreme religious movements. The Maitatsine uprising and the subsequent rise of extreme religious groups in Nigeria, has been associated with an unprecedented politicization of identitybased conflicts on the one hand (Ikelegbe, 2005: 77), and the erosion of a sense of common citizenship fostered by state contraction and popular disillusionment with local politics on the other (Hutchful and Aning, 2004: 203). Incidentally, many of the factors - such as socio-economic grievances, widespread elite corruption, and religious politicization - that were adduced for the Maitatsine uprisings are still present in Nigeria and are implicated in the ontology of the Boko Haram crisis (Adesoji, 2010: 100).

The religious and political waters were muddied when the Nigerian government made a surreptitious decision in 1986 to join the 45-member Organisation of Islamic Conference (OIC), "within which Saudi Arabia and Iran - with their contending visions of Islamic society - strive for political dominance" (Haynes, 1996: 213). Many Christians in the country believe that the OIC was an organization that promotes the religion of Islam, which requires member countries to be headed by Muslims and encourages the implementation of Islamic legal and social norms (Hunwick, 1992: 150). Thus, they fear that the inclusion of Nigeria in the OIC will inevitably lead to the Islamization of the country; a situation that may render them insignificant in the Nigerian public space. Given this dissention, the OIC issue was eventually shelved. That notwithstanding, bouts of religious violence raged on in the country. A prime example was the 1987 religious violence between Christian and Muslim students at the College of Education, Kafanchan. What is more, the religious crisis which broke out in Katsina on 27 March 1991, the Kano uprising of 26 December 1994, and the kidnapping of a Christian preacher by a Muslim group in Kafanchan on 6 September 1996 (Mu'azzam and Ibrahim, 2000: 70), demonstrate rather starkly the degree to which religion has become a pliable tool for violent conflicts in Nigeria. Sometimes, as in February and April 1992 in the Zangon-Kataf crisis, "the conflict was communal - fought over land - but found expression in a religious differentiation" (Gboyega, 1997: 192). Whatever form they took, these crises sowed the seeds of bitter rivalry, suspicion, and discord between Christians and Muslims in Nigeria from the 1990s onwards.

With the historic return to democratic rule in 1999 there were hopes that the new dispensation would pave the way for national cohesion and provide multifaceted outlets for political energies in Nigeria (Hunwick, 1992: 155). But this hope was dashed as about 8 months following the commencement of Nigeria's fourth republic in May 1999, the governor (Ahmed Yerima) of one of the northern states (Zamfara) adopted Sharia law in January 2000. Given the waves of Sharia implementation and enforcement in Zamfara State, eleven other northern States followed suit. According to Afrobarometer (2009: 4), the use of Sharia law by some northern politicians in the year 2000 was a strategy allegedly geared at reclaiming their lost political power which they had hitherto benefited immensely from during the colonial era and the decades in which Nigeria 


\section{Journal of Terrorism Research}

was ruled by northern politicians and generals. However, Ahmed Bello Mahmud, the then-Commissioner of Justice in Zamfara State, justified the adoption and implementation of Sharia law during this period thus: The adoption of the Sharia law by any State that professes the true Islamic faith is not a matter of choice; it is compulsory given the advent of democracy, constitutionalism, and a federal system of government that provides the perfect setting (Mahmud, 2000: 175). Whatever the merits of these two claims, events that preceded the implementation of Sharia law in the twelve religiously mixed northern States revealed the dangers and repercussions of imposing religious laws in a pluralistic country like Nigeria. According to Ibrahim (1991: 130), the outcomes of such religious decisions,

Sets in motion a process of brinkmanship that poses serious threats to the unity of Nigeria, as complex, multiple, and overlapping divisions and contradictions are reduced to two mutually exclusive primordial camps. Nigerians who in their real lives combine their Christianity or their Islam with 'pagan practices', and who are ideologically 'progressives' or 'conservatives', 'fundamentalists' or even 'atheists', are all pushed into two neat and opposed camps - soldiers of either God or Allah.

The net effects is that the mobilization of religion for political purposes and its resulting violence and intolerance laid the foundation for the "Talibanization of Nigeria" (Afrobarometer 2009: 1), which in recent times, has manifested violently in the Boko Haram crisis. In other words, the demand for the implementation of Sharia law by some Nigerian politicians, combined with the long history of religious politicization, fundamentalism, and revivalism in Nigeria to spawn the rise and radicalization of Boko Haram.

\section{Implications and Consequences}

Faced with considerable pressure, the Jonathan Administration recently moved to grant amnesty to Boko Haram despite pleas and criticism from civil society groups and the Christian Association of Nigeria (CAN). These groups argue that, besides being insensitive to the victims of Boko Haram violence, offering amnesty to Boko Haram will only infuse a culture of sheer impunity and senseless violence in the country. As it turns out, Boko Haram rejected the proposed amnesty plan, claiming that it had committed no wrong. Where the 'amnesty strategy', seemed to have 'worked' in the case of the Niger Delta militants, the religious objectives of Boko Haram are, in every practical sense, impossible to realize in a heterogeneous society like Nigeria. There is also no guarantee that even if the sect were to be granted amnesty, it would give up on its demands for the implementation of Sharia law across the country. Additionally, the fact that Boko Haram has split into factions in recent times, makes the possibility of an amnesty offer unlikely to address the crisis as there might be a faction of the sect that remains moderate and open to negotiation, while another remains violent and interested in the nationwide implementation of Sharia law (Forest, 2012: 2).

With the proposed amnesty plan debunked by Boko Haram, the prevailing strategy used by the Nigerian government to curb the crisis is the declaration of a 'State of Emergency' and its attendant deployment of the military and other state security forces to the flashpoints of the group's activities. However, given the escalation of Boko Haram's violent activities, Salkida (2012) argues that the military strategy is utterly undefined and seems unlikely to address the issue, which will require much deeper and sophisticated political engagement. This paper does not claim to have a grand strategy for addressing religious politicization and the Boko Haram crisis in Nigeria. However, a number of points that could manage the crisis and other forms of identity fragmentations in Nigeria are worth emphasizing by way of recommendation: First, in addition to the measures already taken by the Nigerian government to manage Boko Haram and other forms of identity crisis in the country, the idea of organizing a Sovereign National Conference (SNC) should be carefully revisited and considered. Stakeholders in Nigeria have, since the 1980s, been agitating for a SNC in order to 
discuss and address the divisive issues that have stalled harmonious relationship among the different religious and ethnic groups in Nigeria. Although the repressive military regime of Babangida (1985-1993) interfered with the prospect of organizing the conference in the 1980s, it is important for the present crop of Nigerian leaders to revisit the idea again. But for this to work, the Nigerian political class and the citizens must show unwavering willingness to genuinely participate in the conference and put aside their ethnic and religious divisions to freely debate, compromise, negotiate, and design the nature of their society (Rashid, 2004: 388).

Second, the political parties in the country need to articulate their policies using the vernacular of patriotism in order to be able to work toward building a national political philosophy; effort must also be made to achieve a more cohesive political class by making political parties more integrative. A good step in this direction would be to limit the vast number of political parties in Nigeria in order to checkmate the interethnic, inter-religious, and inter-regional conflicts which has inundated Nigeria's political landscape since the attainment of independence in 1960. Where political parties, politicians, and other stakeholders become non-partisan and dissociated from identity politics, the country could be able to address the pitfalls of the colonial and postcolonial leaders who played critical roles in entrenching identity politics in their struggle for the control of resources and of the central government. Akin to the task of decolonization and deimperialization, this exercise can be a painful process involving the sustained "practice of self-critique, selfnegation, and self-rediscovery" (Ndlovu-Gatsheni, 2013: 348). However, if the political will to follow through on reorganisation and national unity is demonstrated and continuous, the Nigerian leaders would be able to engage more meaningfully the tasks of nation-building. There can be no compromises in these tasks if Nigeria is to move ahead peacefully.

\section{Conclusion}

The argument advanced in this paper is simply that to fully understand the Boko Haram crisis, in order to counter it effectively, it is important to understand also how religion has been politicized in Nigeria for the achievement of certain political and economic goals. The analysis on the historical and contemporary processes of religious politicization in Nigeria evinces the fact that the Boko Haram crisis is not an entirely new phenomenon, but that it is part of the broader range of political/religious activism that has dotted the history of northern Nigeria since the Usman Dan Fodio's Jihad in the 19th century. As aptly noted by Lewis (2002: 4), Boko Haram's calls for justice - through the Sharia - clearly reflects another form of violent religious activism, which draws its authority from the lineage of the historical jihad of Dan Fodio and the establishment of the Sokoto Caliphate. According to Salifu (2012), these historical influences on Boko Haram continue to entrench the group as a domestic challenge to Nigeria. Viewed through this prism, the rise and radicalization of Boko Haram poses few mysteries. But in bringing these facts steadily into an analytical view, it is important to keep at a distance the conspiracy theories that proliferate in the minds of an unsettled public opinion or popular misconception -- seeing Boko Haram as an Islamic conspiracy against Christians or as a destabilizing force against the government of President Goodluck Jonathan or even as merely a consequence of state fragility in Nigeria. In the final analysis, understanding how religion could be easily rationalized by certain people in pursuit of self-interested goals is important in not only providing a nuanced understanding of the Boko Haram phenomenon but in informing a prudent and coordinated counterterrorism response that could have the greatest positive impact. 


\section{Journal of Terrorism Research}

About the author: Benjamin Maiangwa is a graduate scholar at the Institute for Sustainability and Peace, United Nations University, Tokyo, Japan. He holds an M.A. in Conflict Transformation and a B.A. (Hons) in Political Science from the University of KwaZulu-Natal, South Africa. His research and writing have focused on Jihadist terrorism and ethno-religious violence in Africa; ECOWAS security architecture; and human rights and development. He may be contacted via email at: < bennymaiangwa@gmail.com>

\section{References}

Adesoji, A.O. 2010. Restoring Peace or Waging War: Security Agencies Management of Ethno-Religious Uprisings in Nigeria, African Security Review 19 (3): 2-14.

Agbiboa, D. 2012. Religious and Cultural Systems as Agents of Change in Developing Areas. The Journal of Social, Political, and Economic Studies, Vol 37(2): 199-221.

Alao, A. 2009. Islamic Radicalization and Violence in Nigeria. Country Report, pp. 1-86.

Afrobarometer, 2009. Popular Perceptions of Sharia Law in Nigeria. Afrobarometer Briefing Paper, 58: 1-12.

Aljazeera, 13th August 2013. Dozens Killed in Nigeria Mosque Attacks. http://www.aljazeera.com/news/ africa/2013/08/2013812204516638370.html [accessed 13 August 2013].

Baylis, J. and Smith, S. 2001. The Globalization of World Politics: An Introduction to International Relations (3rd Ed.). Oxford: Oxford University Press.

Castells, M. 2004. The Power of Identity. Malden, Oxford and Victoria: Blackwell Publishing.

Cook, D. 2011. Boko Haram: A Prognosis. James A. Baker III Institute for Public Policy, 1-33.

Falola, T. and Njoku, R.C. 2010. War and Peace in Africa: History, Nationalism and the State. Durham:

Carolina Academic Press.

Forest, J.J.F. 2012. Confronting the Terrorism of Boko Haram in Nigeria, JSOU Report 2 (5): 1-178.

Gboyega, A. 1997. Nigeria: Conflict Unresolved. In: Conflict Management: Politics and Violence in West Africa, Zartman, I.W. et al, (eds.), pp. 149-196. Washington, D.C.: Brookings Institution Press.

Haynes, J. 1996. Religion and Politics in Africa. London: Zed Books.

Hoffman, B. (1998) Inside Terrorism. New York: Columbia University Press.

Hoffman, B. 1999. Terrorism Trends and Prospects. In: Lesser, I.O. Hoffman, B. Arquilla, J. Ronfeldt, D. and Zanini, M. eds. Countering the New Terrorism. Washington, D.C.: Rand. 7-38.

Hunwick, J. 1992. An African Case Study of Political Islam: Nigeria. Annals of the American Academy of Political and Social Science Vol 524: 143-155.

Hutchful, E and Aning, K. 2004. The Political Economy of Conflict. In: West Africa's Security Challenges: Building Peace in a Troubled Region, Adebajo, A and Rashid, I (eds), pp. 195-222. London: Boulder.

Ibrahim, J. 1989. The Politics of Religion in Nigeria: The Parameters of the 1987 Crisis in Kaduna State. Review of African Political Economy 45 (46): 65-82.

Ibrahim, J. 1990. Religion and Political Turbulence in Nigeria. Journal of Modern African Studies 29 (1): 115136.

Ikelegbe, A. 2005. The Construction of a Leviathan: State Building, Identity Formation and Political Stability in Nigeria. In: The Crisis of the State and Regionalism in West Africa, Fawole, W. A. \& Ukeje, C. (eds), pp. 71- 


\section{Journal of Terrorism Research}

92. Dakar: CODESRIA.

Jefferis, J.L. (2010) Religion and Political Violence: Sacred Protest in the Modern World. New York: Routledge. Kenny, J. 1996. Sharia and Christianity in Nigeria: Islam and the Secular State, Journal of Religion in Africa 29(4): 338-364.

Levitzion, N. 2000. The History of Islam in Africa. Oxford: James Curry.

Lewis, P.M. 2002. Islam, Protest, and Conflict in Nigeria. CSIS Africa Note 10: 1-10.

Mahmud, A.B. 2000. On the Adoption and Implementation of the Sharia Legal System in Zamfara State. In: Sharia Implementation in Northern Nigeria 1999-2006: A Source Book, Ostien, P. (ed). http://www.sharia-inafrica.net/media/publications/sharia-implementation-in-northern-nigeria/vol 24 chapter 2 part III.pdf [accessed on 7 December 2012].

Maiangwa, B. 2013. Killing in the Name of God? Explaining the Boko Haram Phenomenon in Nigeria. The Journal of Social, Political and Economic Studies Vol 38(1): 55-79.

Maier, K. 2000. This House has Fallen: Nigeria in Crisis. London: Penguin Books.

Mu'azzam, I. And Ibrahim, J. 2000. Religious Identity in the Context of Structural Adjustment in Nigeria. In: Identity Transformation and Identity Politics Under Structural Adjustment in Nigeria, A. Jega (ed.), pp. 62-85. Nordiska Afrikainstitutet, Uppsala in collaboration with The Centre for Research and Documentation, Kano. Mustapha, A. 2012. Boko Haram: Killing in God's Name: http://mg.co.za/article/2012-04-05-boko-haramkilling-in-gods-name [accessed on 22 April 2013].

Ndlovu-Garahwni, S.J. 2013. The Entrapment of Africa within the Global Colonial Matrices of Power: Eurocentrism, Coloniality, and Deimperialization in the Twenty-first Century. Journal of Developing Societies Vol 29(4): 331:343.

Neuman, P.R. 2013. The Trouble with Radicalization. International Affairs Vol 89(4): 873-893.

Onuoha, C.F. 2010. The Islamist Challenge: Nigeria’s Boko Haram Crisis Explained. African Security Review 19(1): 54-67.

Paden, J.N. 1981. Islamic Political Culture and Constitutional Change in Nigeria. In: Perspectives on the Second Republic in Nigeria, Whitaker, C.S. (eds.), pp. 24-28. Massachusetts: Press Crossroads.

Rashid, I. 2004. West Africa's Post-Cold War Security Challenges. In: West Africa's Security Challenges: Building Peace in a Troubled Region, Adebajo, A. \& Rashid, I. (eds.), pp. 383-394. London: Lynn Reiner Publishers.

Salifu, U. 2012. Understanding the Dynamics of Islamic Radicalism in Nigeria is key to Bringing Boko Haram to Book. Institute for Security Studies. http://www.issafrica.org/iss-today/understanding-the-dynamics-ofislamic-radicalism-in-nigeria-is-key-to-bringing-boko-haram-to-bookhttp://www.issafrica.org/iss-today/ understanding-the-dynamics-of-islamic-radicalism-in-nigeria-is-key-to-bringing-boko-haram-to-book [accessed 9 January 2014].

Salkida, A. 2012b. Another Look at the Boko Haram Philosophy. http://www.internationalpeaceandconflict. org/profiles/blogs/http-another-look-at-the-boko-haram-philosophy-ahmad-salkida\#.USZsGaUjB0l [accessed on 22 February 2013].

Sampson, I.T. 2012. Religious Violence in Nigeria: Causal Diagnosis and Strategic Recommendations to the State and Religious Communities. African Journal on Conflict Resolution, Vol 12(1): 103-134. 